Anatoly Stepanov*, Alexander Burnasov*, Maria Ilyushkina* *, Yury Kovalev*

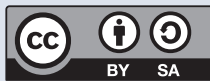

\title{
HIDDEN GEOGRAPHICAL \\ OPPORTUNITIES FOR CONVERGENCE OF RUSSIAN-KAZAKH BORDER AREA
}

Izvirni znanstveni članek

COBISS 1.01

DOI: 10.4312/dela.53.97-110

\section{Abstract}

The study of cross-border interactions of the former Soviet republics is in the centre of research of many experts in border studies. Dynamics and positive effects of convergence processes are observed in the border regions of the Russian Federation and the Republic of Kazakhstan. The past five years have clearly demonstrated the hidden geographical potential of cross-border cooperation between these states, which is explained by a qualitatively new phenomenon in the post-Soviet space - the formation of the Eurasian Economic Union (EAEU). Therefore, the top-down initiatives have strengthened the processes of economic, social, cultural and political convergence of the regions of Russia and Kazakhstan. The purpose of this study is to consider the overlap and the double effect of "hidden" and "formal" integration of border regions of Russia and Kazakhstan and to assess their impact on the social and economic development of border territories.

Keywords: Russian Federation, Republic of Kazakhstan, cross-border cooperation, convergence, integration.

${ }^{*}$ Department of International Relations, Ural Federal University, Lenin Street, 51, Yekaterinburg,

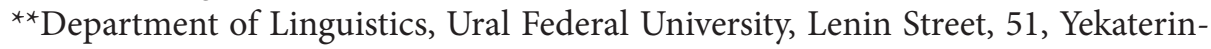
burg,

e-mail: anatoly_stepanow@mail.ru,burnasov@mail.ru, ilyushkina_maria@mail.ru, yykowaljow@gmail.com 


\section{SKRITE GEOGRAFSKE PRILOŽNOSTI ZA KONVERGENCO RUSKO-KAZAHSTANSKEGA MEJNEGA OBMOČJA}

\section{Izvleček}

Proučevanje čezmejnih interakcij nekdanjih sovjetskih republik je v središču raziskovanja številnih strokovnjakov s področja mejnih študij. Dinamika in pozitivni učinki konvergenčnih procesov so bili obravnavani na mejnih območjih Ruske federacije in Kazahstana. Minulih pet let je jasno demonstriralo skriti geografski potencial čezmejnega sodelovanja med temi državami, kar je mogoče pojasniti s kvalitativno novim fenomenom $\mathrm{v}$ postsovjetskem prostoru - oblikovanjem Evroazijske gospodarske unije (EAEU). Potemtakem so pobude od zgoraj navzdol okrepile procese gospodarske, družbene in politične konvergence regij Rusije in Kazahstana. Namen te raziskave je torej proučiti prekrivanje dvojnega učinka skrite in formalne integracije mejnih regij Rusije in Kazahstana in oceniti njihov učinek na družbeni in gospodarski razvoj mejnih območij.

Ključne besede: Ruska federacija, Republika Kazahstan, čezmejno sodelovanje, konvergenca, integracija

\section{INTRODUCTION}

The historical background of the convergence of the Russian and Kazakhstan border should be sought in the $18^{\text {th }}-19^{\text {th }}$ centuries when the expansion of the Russian Empire reached the lands of the nomadic people of Central Asia.

The fundamental principle of the future frontier was Cossack defensive line that arose on the southern and eastern borders of the Russian Empire. In the $18^{\text {th }}$ and $19^{\text {th }}$ centuries the fortified line along the Irtysh River marked the beginning of Omsk, Semipalatinsk, Koryakovsk (modern Pavlodar) and Ust-Kamenogorsk; the fortified line along the river Ishim modern Kurgan and Petropavlovsk; and Orenburg line of fortresses Orenburg, Uralsk, Chelyabinsk, Troitsk, Sol-Iletsk and Atyrau. Each of these lines reflects the historical position of the frontier between the settled and nomadic population, continuous and focal development.

In 1922, the USSR was proclaimed, and the Kazakh Autonomous Soviet Socialist Republic (KazASSR) was formed as part of the Russian Federation, which led to the demarcation of the Russian and Kazakh territories around 1925. The increase in the status of Kazakh autonomy as part of the RSFSR to the Kazakh Soviet Socialist Republic (KAZSSR) in 1936 actually formed the borders of the future independent Kazakhstan.

The economic and geographical discourse of border regions convergence can be studied from several perspectives. Firstly, we should note the geopolitical studies, which reflect the problems of correctness of drawing state borders in the post-Soviet space after 
1990s. Secondly, we can clearly observe the population paradigm in border relations, where a person is embedded in the system of interdisciplinary analysis of demographic, ethnic and urban processes. The third aspect of cross-border research in the post-Soviet space is focused on the economic processes within the emerging Eurasian Economic Union with the developing free market for goods, capital, services and labour. And, finally, the fourth direction is the formation of border regions (analogous to Euroregions) which solves common social and economic problems in the border territories. From this perspective, the studies of political and economic geography of border territories are very interesting, considering "innovative regions" (Burnasov et al., 2017), "border infrastructure" (Golunov, 2009), "territories of advanced development", the influence of transnational companies on border regions with high competitive advantages (Bashmakov, 2013), "agglomeration effect" of border cooperation (Dodonov, 2017).

The problematic field of the present study lies within the hidden geographical possibilities of convergence process in border regions. It is based on the proposition of rapid pace of socio-economic development in converging border regions due to the synergistic effects of cross-border cooperation, higher cooperation of national actors, and the elimination of barriers to interstate interaction. Analysing the convergence of border regions, the authors proceed from the fact that these processes contribute to a more sustainable development of border administrative units and to the convergence of their levels of social and economic development. They also increase the living standards of the population and reduce the degree of polarization of the regions. Summarizing the current theoretical achievements in the field of convergence of regional development, we should note that a so-called neoclassical approach is the most popular view in the scientific literature in its application to regional territories.

\section{METHODS}

The theoretical basis of the current research is formed by the works by Stüben (2005), Eltges (2013), Scholz, Dörrenbacher and Renning (2019), and Vardomsky (2009). The empirical basis of the research includes the use of the materials of the national statistical services of the Russian Federation and the Republic of Kazakhstan, statistics of different departments, reports on financial and economic activities of the companies and corporations, and regional and national regulations that characterize the cross-border cooperation. Convergence processes in the cross-border development of the regions of Russia and Kazakhstan are partly due to a complex of interrelated factors, such as:

1. historical factors, which may concern the history of the state border formation and the stages of border development and its potential over a long period of time;

2. economic factors, aimed at assessing various components of the economic potential, including the natural and human capital of border territories and their foreign economic relations, the prerequisites and problems of creating special 
economic zones in the border area, other institutional instruments of economic development, its problems and prospects;

3. spatial factor, aimed at identifying border and cross-border territories, their structure, assessment of natural resources, environmental, economic and geographical factors of their long-term sustainable development;

4. geopolitical factor, aimed at studying the role of geopolitical position of cross-border territories in regional development, the formation and interaction of geopolitical interests and geopolitical potential of neighbouring countries in their border zones. Existing and potentially possible conflict situations in the border area may be a specific subject of the research.

\section{RESULTS AND DISCUSSION}

In general, the research hypothesis suggests that the convergence of "hidden geographical" opportunities for the development of border territories of Russia and Kazakhstan is possible as a result of the following factors:

1. Social factors of convergence of the borders between Russia and Kazakhstan. The fact that in the $20^{\text {th }}$ century the borders of the Soviet Union republics were quite nominal created prerequisites for a common linguistic and educational space. During the transition from a planned administrative model to a market economy, there were no problems of social tension in the borders of Russia and Kazakhstan. Crossing the border possessed no difficulties due to the political agreements between two countries. In particular, citizens of Russia and Kazakhstan could cross the state border using their ID.

2. Geographical location as a "hidden" possibility of convergence of border regions, one-and-a-half-hour accessibility to the nearest regional centre, both in the Russian Federation and in Kazakhstan (approximately $150 \mathrm{~km}$ ). However, this is not as important as the proximity of a transport crossing. Taking this factor into account, we can consider the border area as a border zone with expanding sections stretched along transport approaches to the border.

3. Economic factors through interconnection of transport networks and socio-economic systems of neighbouring countries. A specific infrastructure of the border area of Russia and Kazakhstan was formed in the Soviet times, which we consider to be a "hidden possibility" of convergence: checkpoints, often accessible for different types of transport, energy facilities built in the Soviet era for the needs of a single national economic complex and the objects of border, customs and other control services, communication, banking, currency, information, tourism, trade and other services that have been developing since the beginning of the 1990s. Thus, the border territory of Russia and Kazakhstan has gained a significant transit potential (a hidden geographical opportunity for logistics 
development), since the export and import of the cargo from other territories and regions is carried out through its transport communications. As a result, multifunctional bilateral cross-border complexes were formed in the Russian-Kazakh border area. Each of them consists of a pair of settlements that are steadily connected by transport links and perform various foreign economic functions. In the future, they can become multi-sectoral cross-border socio-economic systems with a special regime of functioning and regulation. Special intergovernmental long-term agreements within the framework of the EURASEC integration should play an important role in the management of such systems. International coordinating commissions consisting of business representatives and regional authorities can act on the basis of these agreements. (12 Russian regions (the Republic of Altai, the Altai territory, Novosibirsk, Omsk, Tyumen, Kurgan, Chelyabinsk, Orenburg, Samara, Saratov, Volgograd, Astrakhan regions) and 7 Kazakhstan regions (Aktobe, Atyrau, West Kazakhstan, Kostanay, Pavlodar, North Kazakhstan, East Kazakhstan regions) are involved in cross-border economic cooperation.)

4. The "hidden" opportunity of extensive use of the resources and potential of the neighbouring country's border (Russia has the longest border with Kazakhstan - 7512 $\mathrm{km}$, which makes it particularly important for cross-border cooperation between these countries), including its land, forest, water, mineral, recreational and other natural resources.

5. The probability of involving a significant part of the border area population in various forms of interaction (up to $50 \%$ of the employed population) and the use of labour resources of the neighbouring region. Moreover, the potential for developing markets in the territories adjacent to the border on the other side is quite huge. In some cases, these markets may be formed as cross-border ones. At the same time, the market space is significantly expanding (the total gross product of the Russian-Kazakh border area exceeds $\$ 350$ billion).

6. The "hidden" possibility of developing interconnected combinations of various types of activities in the border area on the basis of mutually beneficial international cooperation in the field of trade, export-oriented industries, including small and medium-sized enterprises, industries for processing imported raw materials and semi-finished products, tourist companies and international tourism facilities, cultural and educational services, etc. At the same time, both traditional and new technologies available in neighbouring countries can be used effectively.

7. Creating specific institutions, norms and restrictions for individual border areas, such as duty-free trade zones, visa-free exchange zones, simplified control zones, etc. 


\subsection{Convergence of hidden economic and geographical opportunities of the Russian-Kazakh border area}

In the era of planned administrative economy and the existence of a single state (USSR), the Russian-Kazakh border area was developing within a single national economic complex. Extensive development of industrial production within the so-called "territorial production complexes" contributed to the industrialization of the Russian-Kazakh border area. The most important industrial facilities were built here at the turn of the 1950s and 1960s. They still retain their industrial potential for the border regions of Russia and Kazakhstan. In the Soviet period, the Kazakh border was considered to be a source of raw materials for manufacturing enterprises of the Russian Federation. As a result, even today there are value chains in the fuel and energy complex (oil and gas fields of Western Kazakhstan), oil and gas processing plants in Russia (Orenburg and Samara regions), coal mining in Ekibastuz (Pavlodar region, Kazakhstan) and electricity generation at thermal power plants of the Russian border (Omsk and Chelyabinsk regions). The metallurgical complex of the Russian-Kazakh border region has maintained stable connections in the production of ferrous metals: Sokolovsko-Sarbayskoye deposit of high-quality iron ores (Kazakhstan) with the production of cast iron, steel and rolled products at the Chelyabinsk and Magnitogorsk metallurgical works (Russia). A clear example of interconnection and interdependence in non-ferrous metallurgy can be the production of chromium by Novotroitsk chrome products plant, which has increased production of goods with high added value (metal and electrolytic chromium) by increasing imports of chrome ore from the Aktobe region of Kazakhstan in recent years.

"Production for production's sake" was considered the main indicator of territorial development during the period of planned economy. It led to the closure of a significant number of "city-forming" enterprises of the Soviet era (Pavlodar tractor plant) or to the transformation of enterprises of the military-industrial complex (Petropavlovsk heavy engineering plant in Kazakhstan). Since the early 1990s, gaining profit has become the main indicator of doing business in both countries. This explains the modern interaction of multinational companies in the Russian-Kazakh border area in the system of continuous cycles of added value creation. For example, on the industrial site of the former Pavlodar tractor plant, Kazakhstan Corporation KSP Steel launched the production of large diameter seamless pipes for gas and oil pipelines, including the ones for enterprises of the Russian fuel and energy complex, while Petropavlovsk heavy engineering plant, which specialized in defence products in the Soviet years, passed the conversion stage and moved into the market era, producing oil drilling equipment and machinery as well as the equipment for the construction and maintenance of railway tracks, including the ones for Russian consumers.

The entrepreneurship of corporations in the field of mechanical engineering should be mentioned among the most striking examples of hidden economic and geographical opportunities of the Russian-Kazakh border area at the beginning of the 
$21^{\text {st }}$ century. The most successful of more than a hundred joint ventures of Russia and Kazakhstan operating in the border area are the following:

A business project of the $\mathrm{X}$-ray diagnostic equipment production: led installations, radiation protection equipment, mammography devices, fluorography devices, mobile laboratories of the Aktyubrentgen Plant (Kazakhstan), which carries out scientific cooperation with the Orenburg LLC Uralrentgen (Russian Federation) (Aktyubrentgen, 2019).

Investment of the Russian capital in transport engineering in Kazakhstan. The creation of KAMAZ trucks production with high localization is also among the successful projects. AO KAMAZ-Engineering is one of the first major and successful KazakhRussian joint cross-border projects in the field of automotive equipment production in Kokshetau. The company was established on June 2, 2005, and on August 5 of the same year the first dump truck and bus were assembled, and on August 19, 2005 the first production vehicle rolled off the production line. All manufactured products are sold on the domestic market of the Republic of Kazakhstan. AO KAMAZ-Engineering in Kokshetau is created in accordance with the licensing agreements with OAO KAMAZ and OAO NefAZ, which provide Kazakhstan's partner with the design documentation of Russia's leading car factories. The assembly process is organized in accordance with this documentation. This joint venture has produced more than 13,000 vehicles and special equipment since its creation. The production capacity of the plant is 1500 trucks per year. The range of products of the Kazakh enterprise includes 50 types of KAMAZ vehicles, including dump trucks, tractor units, dropside trucks and all-wheel drive vehicles, as well as 35 types of special vehicles (Autostat, 2019).

Formation of a regional automobile cluster in East Kazakhstan on the basis of AO Asia Auto Kazakhstan in Ust-Kamenogorsk. In 2000, the government of Kazakhstan decided to create a car factory for the production of passenger cars. The Russian company AVTOVAZ was considered a possible investor. As a result, 20 years later, not only AVTOVAZ models (Vesta, XRAY, Granta), but also Škoda (Octavia) and KIA (Sportage, Serato, Sorento) models are produced in Ust-Kamenogorsk (Aziaavto, 2019). The governments of both countries often consider these joint ventures as successful projects of the EURASEC integration. It is a well-known fact that one job created in the automotive industry automatically creates four jobs in related industries. This car factory will give an additional economic impulse of industrial convergence to the enterprises of metallurgical and chemical complexes of the border regions: the Altai territory and East Kazakhstan region.

One of the factors that could negatively affect the regional convergence of the Russian-Kazakh border area is the outflow of Russian-speaking residents of Northern Kazakhstan to the territory of the Russian Federation. A number of researchers (Burnasov et al., 2019; Karpenko, 2019; Vardomsky, 2019) objectively noted the current trend of the last thirty years such as the Russian-speaking population (Russians, Ukrainians, Belarusians) leaving Kazakhstan in search of permanent residence in Russia. 
In particular, M. Karpenko's work shows a negative picture of the migration balance at the entire Russian-Kazakh border area. The researcher explains this situation mainly by "kazakhization" of the Northern regions of Kazakhstan, which has been traditionally characterized by a high share of the Russian-speaking population. However, the state program of the Republic of Kazakhstan for the resettlement of oralmans (ethnic Kazakhs who lived outside the Republic of Kazakhstan in recent years (2016-2019)) has not been successful enough, which gives a chance to maintain a balance between the Russian-speaking and Kazakh population in the border area.

Figure 1: Decrease in the share of the Russian population in the border regions of the Republic of Kazakhstan in the period from 1989 to 2016.

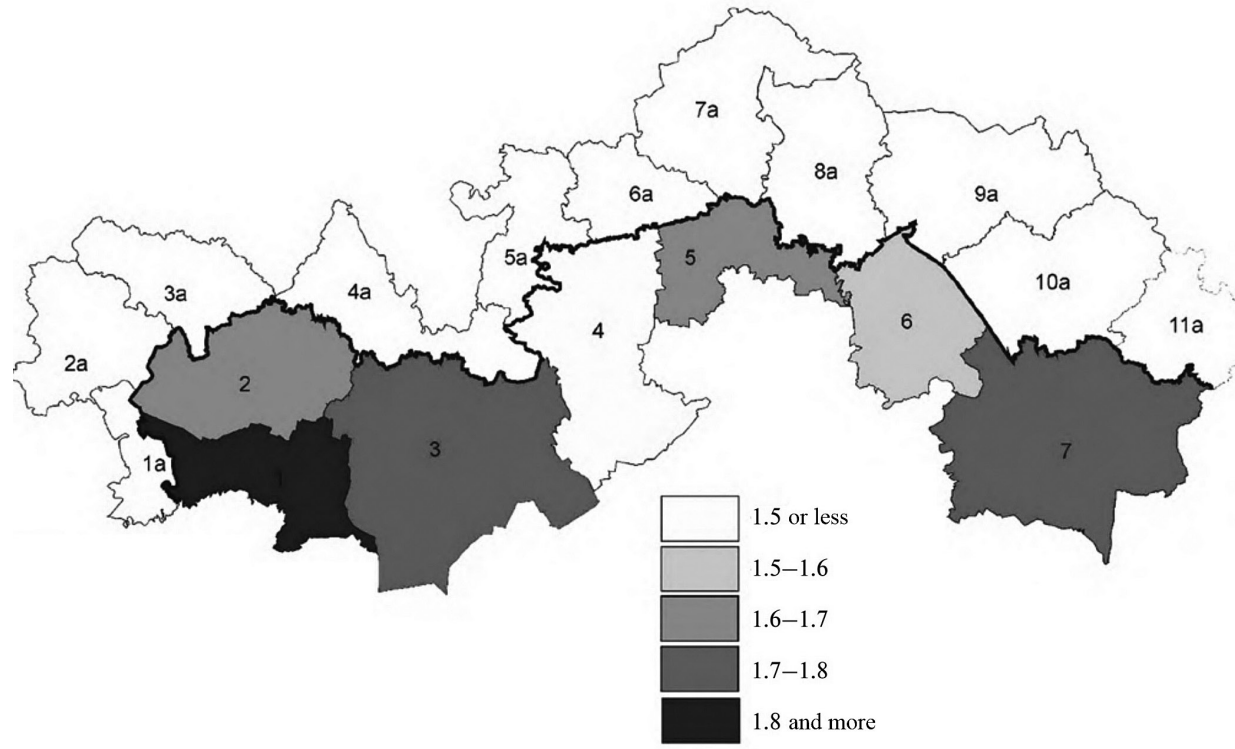

Russian Federation: 1a - Astrakhan region, 2a - Volgograd region, 3a - Saratov region, $4 a$ - Orenburg region, $5 a$ - Chelyabinsk region, 6a - Kurgan region, 7a - Tyumen region, $8 a$ - Omsk region, 9a - Novosibirsk region, 10a - Altai Territory, 11 a - Altai Republic.

The Republic of Kazakhstan: 1 - Atyrau region, 2 - West Kazakhstan region, 3 - Aktobe region, 4 - Kostanay region, 5 - North-Kazakhstan region, 6 - Pavlodar region, 7 - East Kazakhstan region.

Compiled according to Karpenko, 2019, p. 27.

As we can see, Figure 1 represents the outflow of the Russian speaking population (including people from the Ukraine, Belarus, etc.) from the border regions of Kazakhstan to the territory of the Russian Federation. On the basis of the cartogram method (the higher index is in the darker tones) the regions with the maximal outflow are 
shown. It is obvious that the outflow from the Western and the Eastern Kazakhstan was more intense than in the Northern Kazakhstan. It is due to the employment problems as more qualified specialists with particular skills moved to the border areas in search of well-paid positions.

Moreover, the economic development rates of Kazakhstan and Russia in the era of integration development (2013-2019) showed the reverse side of hidden economic and geographical opportunities. In the border regions of Kazakhstan, unemployment rates were lower than in the border regions of the Russian Federation (except for Tyumen and Orenburg regions), which in turn, when creating a common market for goods, capital, services and labour, helped to attract labour from the border regions of Russia to the regions of Northern Kazakhstan (Table 1).

Table 1: Population and unemployment in the border regions of Russia and Kazakhstan (2019).

\begin{tabular}{|l|l|l|l|l|l|}
\hline $\begin{array}{l}\text { Russian } \\
\text { Federation }\end{array}$ & $\begin{array}{l}\text { Population } \\
\text { (thousands } \\
\text { of people) }\end{array}$ & $\begin{array}{l}\text { Unemployment } \\
\text { rate (\%) }\end{array}$ & $\begin{array}{l}\text { The Republic } \\
\text { of Kazakhstan }\end{array}$ & $\begin{array}{l}\text { Population } \\
\text { thousands } \\
\text { of people) }\end{array}$ & $\begin{array}{l}\text { Unemployment } \\
\text { rate (\%) }\end{array}$ \\
\hline $\begin{array}{l}\text { Astrakhan } \\
\text { region }\end{array}$ & 1000.1 & 7.5 & Atyrau region & 646.4 & 4.5 \\
\hline $\begin{array}{l}\text { Volgograd } \\
\text { region }\end{array}$ & 2500.5 & 5.6 & $\begin{array}{l}\text { West } \\
\text { Kazakhstan } \\
\text { region }\end{array}$ & 657.0 & 4.8 \\
\hline Saratov region & 2440 & 5.0 & Aktobe region & 881.7 & 4.8 \\
\hline $\begin{array}{l}\text { Orenburg } \\
\text { region }\end{array}$ & 1963.0 & 4.4 & $\begin{array}{l}\text { Kostanay } \\
\text { region }\end{array}$ & 868.1 & 4.6 \\
\hline $\begin{array}{l}\text { Chelyabinsk } \\
\text { region }\end{array}$ & 3476.0 & 5.6 & $\begin{array}{l}\text { North- } \\
\text { Kazakhstan } \\
\text { region }\end{array}$ & 548.1 & 5.0 \\
\hline Kurgan region & 835.0 & 8.0 & $\begin{array}{l}\text { Pavlodar } \\
\text { region }\end{array}$ & 752.3 & 4.7 \\
\hline Tyumen region & 3723.0 & 3.1 & $\begin{array}{l}\text { East } \\
\text { Kazakhstan } \\
\text { region }\end{array}$ & 1.369 & 4.3 \\
\hline Omsk region & 1944.0 & 6.7 & 6.7 & & \\
\hline $\begin{array}{l}\text { Novosibirsk } \\
\text { region }\end{array}$ & 2793.0 & 11.2 & & & \\
\hline Altai Territory & 2333.0 & 6.1 & & & \\
\hline Altai Republic & 219.0 & & & & \\
\hline
\end{tabular}

Calculated by the authors according to: Regiony Rossii, 2019; Regiony Kazakhstana..., 2019. 
Eurasian integration contributed to the revival of socio-economic processes in the border regions of Russia and Kazakhstan. Among the hidden geographical opportunities, we can consider the potential for the agglomeration effect; in the era of planned economy, border agglomerations were successfully integrated into the structure of emerging territorial and industrial complexes, creating an "agglomeration industrial base" (Atyrau-Astrakhan, Samara-Uralsk, Chelyabinsk-Kurgan-Petropavlovsk, Omsk-Pavlodar, Barnaul-Ust-Kamenogorsk). Now, in the era of market transformations, we can talk not only about growth poles or territories of advanced development, but also about emerging cross-border regions that are of great importance for the economies of both countries (more than $\$ 500$ billion) (Karpenko, 2019); the regions of the Kazakhstan border region contribute $36 \%$ of the country's total GDP. The share of the Russian part of the border area (without the Autonomous districts of Tyumen region) is $12 \%$ (Karpenko, 2019). The existing potential of future cross-border regions can strengthen synergetic effects in the economy, which are expressed in the formation of production and cooperative interregional networks, industrial and regional clusters, unified educational spaces, etc. (Figure 2).

Regional differences in the economic development, specialization, the level and ratio of domestic prices, tax and investment legislation, the income of the population, etc. become an important hidden resource of cross-border cooperation, which allows for an active exchange of relevant goods and factors of production. In short, cross-border cooperation based on the proximity of differences and common resource and geo-economic situation plays an important role in the development of the economy of border territories. 
Figure 2: Borders of the emerging border agglomerations and outlines of cross-border regions of the Russian Federation and the Republic of Kazakhstan.

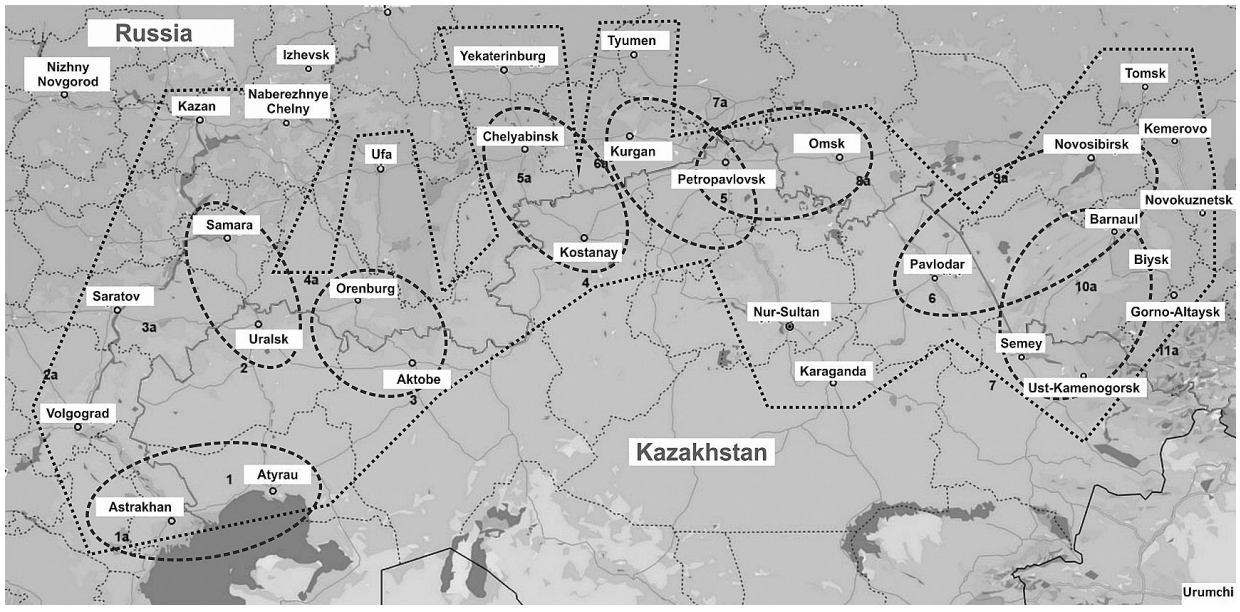

Russian Federation: 1a - Astrakhan region, 2a - Volgograd region, 3a - Saratov region, $4 a$ - Orenburg region, $5 a$ - Chelyabinsk region, 6a - Kurgan region, 7a - Tyumen region, $8 a$ - Omsk region, 9a - Novosibirsk region, 10a - Altai Territory, 11 a - Altai Republic. The Republic of Kazakhstan: 1 - Atyrau region, 2 - West Kazakhstan region, 3 - Aktobe region, 4 - Kostanay region, 5 - North-Kazakhstan region, 6 - Pavlodar region, 7 - East Kazakhstan region.

Created by the authors based on Regiony Rossii, 2019.

\section{CONCLUSION}

In conclusion, it is worth noting that Russian-Kazakh cross-border cooperation has common historical, socio-economic and cultural basis, due to the existence of common federal states on this territory for many centuries. During the Soviet era, the inter-republic space was linked through the creation of a unified transport, production and service infrastructure, and the formation of common goals and development strategies. After dissolution of the Soviet Union and creation of new independent states, Russia continues its rich political heritage and the long national tradition, but in new border situations. However, the influence of the border on the inter-regional interaction here was not as separating as in the other regions of the former USSR (Georgia and Russia, Russia and Estonia). Inter-regional ties, although being weakened, continued to function even during the difficult transition period. Moreover, integration processes in the Eurasian space have strengthened Russian-Kazakh interregional interaction. Economic cooperation between the regions is actively developing within the framework of production networks, inter-regional goods and services exchange. 
What is more, processes of pendulum migrations are observed. The formed common transport corridors play a special role in this sphere and their development in the future has a huge "hidden" geographical potential. The existing settlement system in the border regions is capable of generating high agglomeration effects here. Large cities are the centres of attraction for both human resources and large capital. The border territories have become objects of investment by transnational corporations in the field of automotive, instrumentation and general engineering. The existing educational and innovative potential in the border cities represents a hidden geographical opportunity for the future development of these territories.

The polarized border area is also one of the hidden factors in the development of these territories. The differences in the standards of living, prices, goods and services created, and regional culture can contribute not only to the strengthening of economic and social dynamics in the region, but also to the formation of a wide range of new ideas and prospects for further territorial development. Especially in the periods of crisis (as we can observe now in relation to COVID-19 pandemic), the diversity of border regions becomes the main factor of the regional resistance.

The formation of a common market (as in the EU) becomes an important hidden geographical factor as well. It will lead to the deepening of inter-regional cooperation. Freedom of movement of the capital, goods, services, people and ideas will have a positive impact on the economic growth in the region, social climate and quality of life of the population.

\section{References}

Aktyubrentgen, 2019. Spezialisazija predprijatija AO "Aktubrentgen". URL: http:// www.aktubroentgen.kz/php/index.php?option=com_content\&view=article\&id=39\&Itemid $=88$ (accessed 20.11.2019).

Autostat, 2019. "Kamaz-Inzhiniring" s momenta otkrytija vypustil bolee 12.5 tys. grusovikov. URL: https://www.autostat.ru/news/38478/ (accessed 20.11.2019).

Aziaavto, 2019. Istorija zavoda AZIAAVTO. URL: http://aziaavto.kz/ru/istoriya-zavoda (accessed 20.11.2019).

Bashmakov, A.A., 2013. From border cooperation to Eurasian economic integration. Alma-Aty: Kazakh Institute of strategic research.

Burnasov, A., Ilyushkina, M., Kovalev, Y, Stepanov, A., 2017. Research and development of innovative systems in BRICS countries. Studia Ekonomiczne. Zeszyty Naukowe Uniwersytetu Ekonomicznego w Katowicach, 323, pp. 5-23.

Burnasov, A., Ilyushkina, M., Kovalev, Y, Stepanov, A., Nyussupova, G., 2019. The transformation of economic development in the border regions of Russia and Kazakhstan in the post-Soviet period. Studies of the Industrial Geography Commission of the Polish Geographical Society. Conditions for Regional and local Development, 33, 2, pp. 132-141. 
Dodonov, V., 2017. Economic collaboration between Kazakhstan and EU and social and economic effects. Almaty: Fr, Ebert's Fund.

Eltges, M., 2013. Regionale Konvergenz und Divergenz - die Frage der Fragen. Informationen zur Raumentwicklung, 1, pp. 51-66.

Golunov, S.V., 2009. Cross-Border cooperation of Russia and Kazakhstan: problems and ways of development. Mirovaja ekonomika i mezhdunarodnye otnosheniya, 6, pp. 84-91.

Karpenko, M.S., 2019. Cross-Border dimension of Eurasian integration of Russia and Kazakhstan: Challenges for cooperation. Izvestia RAN. Seria geographischeskaja, 1, pp. 24-36. DOI: 10.31857/S2587-55662019124-36.

Regiony Kazakhstana v 2019 godu. 2019. Statisticheskii ezhegodnik [Regions of Kazakhstan in 2019: Statistical yearbook]. Astana: Ministerstvo Natsionalnoi Ekonomiki Respubliki Kazakhstan.

Regiony Rossii. 2019. Sozialno-ekonomicheskie pokazateli. [Regions of Russia: Socio-economic indicators]. Moscow: Rosstat.

Scholz, C., Dörrenbacher, P., Renning, A., 2019. Europa Jenseits des Konvergenzparadigma. Divergenz-Dynamik-Diskurs. Baden-Baden: Nomos.

Stüben, T., 2005. Regionale Konvergenz und Divergenz. Aachen.

Vardomsky, L.B., 2009. Rossiiskoe porubezhje v usloviyakh globalizatsii [Russian borderlands in the context of globalization]. Moscow: LIBROKOM Publ.

Vardomsky, L.B., 2019. Instituty ili proekty: Evrasiiskaja integrazija nuzhdaetsja v peremenach [Institutes or projects: Eurasian integration needs change]. Problemy sovremennoj ekonomiki, 3, 71, pp. 20-22.

\section{SKRITE GEOGRAFSKE PRILOŽNOSTI ZA KONVERGENCO RUSKO-KAZAHSTANSKEGA MEJNEGA OBMOČJA}

\section{Povzetek}

Proučevanje čezmejnih interakcij na območju bivših sovjetskih republik je v središču zanimanja številnih strokovnjakov, ki se ukvarjajo z mejami. Prispevek obravnava dinamiko in pozitivne učinke konvergenčnih procesov v mejnih regijah Rusije in Kazahstana.

Rusko-kazahstansko čezmejno sodelovanje ima - zaradi obstoja skupnih federalnih držav na tem ozemlju v preteklosti - skupne zgodovinske, socio-ekonomske in kulturne temelje. V času Sovjetske zveze je bil medrepubliški prostor povezan $s$ skupno prometno, proizvodno in storitveno infrastrukturo ter skupnimi razvojnimi strategijami.

Po razpadu Sovjetske zveze in ustanovitvi novih neodvisnih držav Rusija nadaljuje svojo bogato politično dediščino in dolgotrajno nacionalno tradicijo, vendar $\mathrm{v}$ novi 
mejni situaciji. V obravnavanem primeru nova meja na medregionalno interakcijo ni vplivala tako negativno kot $\mathrm{v}$ drugih obmejnih regijah bivše ZSSR (Gruzija in Rusija, Rusija in Estonija). Medregionalne vezi, čeprav oslabljene, so se še naprej ohranjale celo $\mathrm{v}$ času težavnega tranzicijskega obdobja. Povrh tega so integracijski procesi v evrazijskem prostoru okrepili rusko-kazahstansko medregionalno interakcijo. Gospodarsko sodelovanje med regijami se razvija znotraj okvira proizvodnih omrežij ter medregionalne izmenjave dobrin in storitev.

Še več, opaziti je mogoče procese dnevnih migracij. Skupni transportni koridorji igrajo na tem področju posebno vlogo in njihov razvoj v prihodnosti ima velik skrit geografski potencial. Obstoječ naselbinski sistem v mejnih regijah je zmožen generirati intenzivne aglomeracijske učinke. Velika mesta so središča privlačnosti tako za človeške vire kot kapital. Mejna območja so pritegnila investicije s strani transnacionalnih korporacij. Obstoječ izobraževalni in inovacijski potencial v mejnih regijah predstavlja skrito geografsko priložnost za prihodnji razvoj teh ozemelj. Polarizirano mejno območje je tudi eden izmed skritih dejavnikov razvoja teh ozemelj. Razlike $\mathrm{v}$ življenjskem standardu, cenah ter ustvarjenih dobrinah in storitvah ter regionalni kulturi lahko prispevajo ne samo h krepitvi gospodarske in družbene dinamike $\mathrm{v}$ regiji, ampak tudi k oblikovanju širokega spektra novih idej za nadaljnji razvoj. Še zlasti v obdobjih kriz lahko raznolikost mejnih območij postane glavni dejavnik regionalne odpornosti.

Oblikovanje skupnega trga (kot v primeru EU) postaja pomemben skrit geografski dejavnik in bo prispevalo k poglabljanju medregionalnega sodelovanja. Svoboda gibanja kapitala, dobrin, storitev, ljudi in idej bo imela pozitiven učinek na gospodarsko rast v regiji, družbeno ozračje ter kakovost življenja prebivalstva.

(Prevedel Dejan Cigale) 